
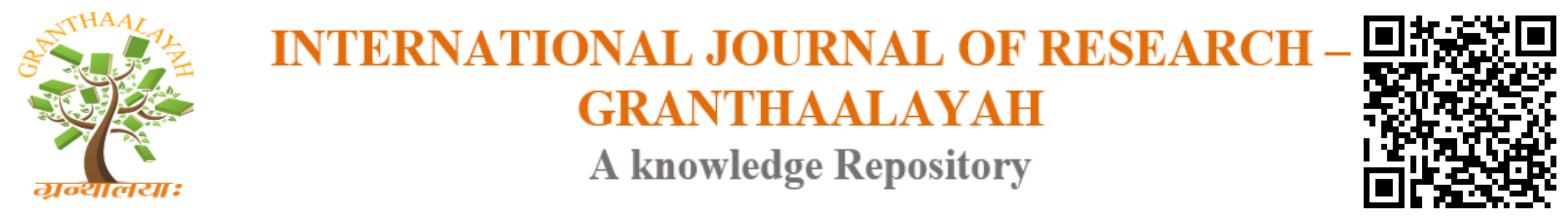

Science

\title{
THE EFFECTS OF SEED'S SIZE, AND REMOVAL TESTA TREATMENT ON GERMINATION RATIO AND PERIOD OF FABA BEAN STORED SEEDS (VICIA FABA VAR. ECUADELJE)
}

\author{
Dara Y. Mohammad 1, Jalal Omer Ahmed ${ }^{2}$, Anwar Rashid Abdulla ${ }^{3}$ \\ 1, 2,3 Protected Agriculture Department, Bakrajo Technical Institute, Sulaimani Polytechnic \\ University, Sulaymaniyah
}

\begin{abstract}
The research was conducted at - Sulaimani Polytechnic Universit (SPU), Bakrajo Technical Institute in Sulaymaniyah city, Iraq in begging of 2018. Three different sizes and varieties Ecuadelje of bean seeds were used and treated. Water-soaking, dilute acid soaking, and dilute base with scarification soaking. They were distributed in 36 pots by using CRBD with three replicates. The results showed the significant differences only with the effect of seeds size from the period of sowing seeds to the end of germination. The small size seeds had significant differences compare to the others. But the effect of removal test was high significant in all studied characteristics. Seeds which socked with diluted base and diluted acid had significant differences compare to the other treatments form the initial to the final stage of seeds germination. The interaction between seeds sizes and removable testa treatment showed significant differences among small size seeds which treated with diluted $\mathrm{HCl}$ during the initial and final stage, and the large size seeds treated with diluted $\mathrm{NaOH}$. Seeds scarification treatment did not show any positive effects in both of germination periods, but showed significant differences in the percentage of initial and final germination. We suggested to sock the broad bean seeds in one of diluted bases or diluted acids and scarification of seed treatment in order to stimulate germination percentage reduce of the germination period and develop broad beans stored seeds germination.
\end{abstract}

Keywords: Faba Beans; Seeds Size; Removal Testa Treatments; Seeds Germination Period; Seeds Scarification.

Cite This Article: Dara Y. Mohammad, Jalal Omer Ahmed, and Anwar Rashid Abdulla. (2018). “THE EFFECTS OF SEED'S SIZE, AND REMOVAL TESTA TREATMENT ON GERMINATION RATIO AND PERIOD OF FABA BEAN STORED SEEDS (VICIA FABA VAR. ECUADELJE)." International Journal of Research - Granthaalayah, 6(3), 166-171. https://doi.org/10.29121/granthaalayah.v6.i3.2018.1510. 


\section{Introduction}

The Faba bean is a major legume in Iraq, because of the high nutritional value which contains many chemical components such as proteins, carbohydrates, vitamins and some mineral elements [1]. Seeds of many bean varieties are associated with germination problems due to an impermeable seed coat $[2,3]$. Therefore, we believed that pre-treat seeds are encouraging to solve such kind of problems. The effect of seed size on the production of dried seed were studied by Wensveen who used four bean seeds sizes (large, medium, small and very small).Wensveen concluded that there were significant differences in the yield of dry grains. Sowing large and medium seeds sizes produced higher yield than small and very small seeds sizes. [4]

The main reasons, of testa in faba bean stored seeds, are hardness of the seeds cover ; decrease in water content of the seeds, produced some inhibitors substances (such as Absisic Acid ABA or Hydrogen Cyanamid $\mathrm{HCN}$ or one of cupper compounds such as cupper sulphate CuSo4), low seed's content of carbohydrate compounds and others. Using of certain plant growth regulators such as Idol Acetic Acid (IAA), Naphthalene Acetic Acid (NAA), Benzoic Acid (BA), Salsalic acid (SA) or others remove the testa.[5]. These growth regulators activated the glucoamylase (aglucosidase) enzyme action during germination [6], the works of this enzyme is to convert starch into glucose sugar whatever such works because the degradation of cellulose in the solid crust of faba bean seeds was studied by Metzgerwho used different concentration $(0.5,1,1,5,2,2.5$ and $3 \mathrm{ml} /$ liter distilled water and both of $\mathrm{HCL}$ and $\mathrm{Ca}(\mathrm{OH})_{2}$. Metzger found that $\mathrm{HCL}$ concentrated 2 $\mathrm{ml} /$ lit water and $\mathrm{Ca}(\mathrm{OH})_{2}$ concentrated $1 \mathrm{ml} /$ lit water achieved better result in the removal of the testa. Metzger concluded that the bases better than the acids in breaking the peptide bonds that link the cellulose molecule in the cells walls.[7]

Dr.Enneking \& Narbon studied the effect of hydrogen peroxide on popcorn Zea maize (old stored seeds germination). They used six transactions to soak seeds $(0,50,100,200,300,400$, $500 \mathrm{ppm}$ ) comparing with soaked with distilled water. They found that soaking seeds with hydrogen peroxide concentrate $0,50,100,200,300$ and $400 \mathrm{ppm}$ respectively stimulated the seeds germination percentage from $41.7 \%$ to the $82.1 \%, 74.5 \%, 66.8 \%, 55.1 \%$ and $46.9 \%$ respectively [8]. Agarwaland his colleagues used two acids (Absisic Acid ABA and Salsalic Acid SA), one alkaline (Calcium hydroxide $\mathrm{Ca}(\mathrm{OH}) 2$ ) and (hydrogen peroxide $\mathrm{H} 2 \mathrm{O} 2$ ), to removal of the testa from the stored wheat seeds. The concentrations of those four solutions were $0.1 \%$. Agarwaland his colleagues found that ABA had significant effect the removal of the testa on the germination period, followed by the treatment with $\mathrm{H} 2 \mathrm{O} 2$ which is better than the others compounds [9]. Scarification of hard skin stored seeds let to increase the germination percentage. The reason for this is due to the increases of water intake through cracks that occur in those seeds [1].

Although the water enters through the cracks lead to breakdown of complex sugar into simple sugars, as utilized through the development of the embryo seed [10].

\section{Materials and Methods}

The materials used in this research were three different sizes of bean seeds, large $(127 \mathrm{gm} / 100$ seeds), medium ( $79 \mathrm{gm} 100$ seeds) and small (53gm/100 seeds), 36 seeds were used for each size, 36 plastics pots, with $30 \mathrm{~cm}$ in diameter, Soil culture consisting of sand and peat moss 
(2:1), Diluted $\mathrm{HCl}$ acid (concentrated 0.1\%), Diluted $\mathrm{NaOH}$ (concentrated 0.1\%), Distilled water and a Knife were used to make scratches in the crust of the seeds and Plastic labels to write the number of experimental units. Three sizes of seeds were selected (a1, a2, a3) from one $\mathrm{kg}$ Ecuadelje variety dried bean seeds [11]. Four treatments were used (soaking 8 hours with distilled water $\mathrm{b} 0$, dilute $\mathrm{HCl}$ b1, dilute $\mathrm{NaOH}$ b2 and scarification b3) for all sizes of those seeds. After treating of those seeds, they were sown in the pots, with Complete Randomized Block Design (CRBD) in the Factorial Experiments, whereas factor (A) for the sizes (a1, a2, a3), factor (B) for the soaking and scarification treatments (b0, b1, b2, b3) and AB for interactions. At the beginning of seeds germination, data recorded about the different germinations. Statistical analysis was done, ANOVA test was used, the averages of differences compared with the LSD at the level of 0.05 [12].

\section{Results and Discussions}

\subsection{Initial Germination Period}

Table (1) demonstrates that there were no significant differences within 3 seeds sizes of bean. Removal testa treatments showed that short initial germination period achieved when seeds soaked with diluted $\mathrm{HCl}$ acid and diluted $\mathrm{NaOH}$ compared with soaking in distilled water. This indicates that soaking in acids and bases leads to a softer crust of solid seeds and reduce the germination period; this result is with the findings of Weberand his colleagues [13]. Scarified seeds showed no significant differences compared with socking with distilled water. Interaction between seeds sizes and removal testa treatments showed minor differences between medium seeds soaked with diluted $\mathrm{HCl}$ and large seeds soaked with diluted $\mathrm{NaOH}$.

Table 1: Initial germination period for Ecuadelje variety with different seeds size and removal testa treatments

\begin{tabular}{|c|c|c|c|c|c|}
\hline \multirow[t]{2}{*}{ Seeds Size (A) } & \multicolumn{4}{|c|}{ Removal testa treatments (B) } & \multirow[t]{2}{*}{ Mean (A) } \\
\hline & bo & b1 & b2 & b3 & \\
\hline$a_{1}$ & 18.7 & 12.7 & 12.3 & 15.7 & 14.85 \\
\hline $\mathrm{a}_{2}$ & 18.3 & 11.3 & 13.0 & 14.7 & 14.32 \\
\hline$a_{3}$ & 17.3 & 12.3 & 10.7 & 15.7 & 14.00 \\
\hline Mean (B) & 18.1 & 12.1 & 12.0 & 15.4 & \\
\hline \multicolumn{6}{|c|}{$\begin{array}{l}\text { L.S.D } 0.05(\text { A })=6.348 \\
\text { L.S.D }{ }_{0.05}(\text { B })=5.122 \\
\text { L.S.D } 0.05(\text { A X B })=2.867\end{array}$} \\
\hline
\end{tabular}

$\mathrm{a}_{1}=$ Large seeds size $\mathrm{a}_{2}=$ Medium seeds size $\mathrm{a}_{3}=$ Small seeds size $\mathrm{b}_{0}=$ Seeds soaking with water $b_{1}=$ Seeds soaking with diluted $\mathrm{Hcl} \quad \mathrm{b}_{2}=$ Seeds soaking with diluted $\mathrm{NaOH} \quad \mathrm{b}_{3}=$ seeds scarification

\subsection{Final Germination Period}

Table (2), shows that large seeds size got significant differences compared with small seeds size. While removal testa treatments, showed that there were significant differences, when seeds soaked with dilute $(\mathrm{HCl})$ or $(\mathrm{NaOH})$ compared with soaking in water. Scarification did not show any significant differences comparing with socking in water. Interaction between seeds 
sizes and removal testa treatments showed that large and medium seeds treated with $(\mathrm{HCl})$ and $(\mathrm{NaOH})$ caused significant differences in the period from sowing until final germination.

These results indicated that $\mathrm{HCl}$ and $\mathrm{NaOH}$ breaking the peptide bonds that link the cellulose molecules in the cell walls better than scarification and soaking with water as mentioned by Metzger [8].

Table 2: Final germination period for Ecuadelje variety with different seeds size and removal testa treatments

\begin{tabular}{|c|c|c|c|c|c|}
\hline \multirow[t]{2}{*}{ Seeds Size (A) } & \multicolumn{4}{|c|}{ Removal testa treatments $(\mathrm{B})$} & \multirow[t]{2}{*}{ Mean (A) } \\
\hline & $\mathbf{b}_{0}$ & $\mathbf{b}_{1}$ & $\mathbf{b}_{2}$ & b3 & \\
\hline$a_{1}$ & 30.7 & 22.3 & 22.0 & 33.7 & 27.18 \\
\hline $\mathrm{a}_{2}$ & 33.7 & 23.7 & 22.3 & 32.0 & 27.93 \\
\hline$a_{3}$ & 29.7 & 21.0 & 19.3 & 31.7 & 33.67 \\
\hline Mean (B) & 31.37 & 22.33 & 21.20 & 32.47 & \\
\hline $\begin{array}{l}\text { L.S.D } 0.05 \text { ( A ) } \\
\text { L.S.D } \\
\text { L.S.D. }{ }_{0.05} \text { ( B ) } \\
\text { A X }\end{array}$ & $\begin{array}{l}5.794 \\
3.168 \\
3)=2 .\end{array}$ & & & & \\
\hline
\end{tabular}

$\mathrm{a}_{1}=$ Large seeds size $\quad \mathrm{a}_{2}=$ Medium seeds size $\mathrm{a}_{3}=$ Small seeds size $\mathrm{b}_{0}=$ Seeds soaking with water $b_{1}=$ Seeds soaking with diluted $\mathrm{HCl} \quad \mathrm{b}_{2}=$ Seeds soaking with diluted $\mathrm{NaOH} \mathrm{b}_{3}=$ seeds scarification.

\subsection{Initial Germination Percentage}

Table (3) shows that there were not significant differences within the three seeds sizes on initial germination percent. The seeds soaked with $\mathrm{NaOH}, \mathrm{HCl}$, and Scarification got significant differences comparing with soaking in water, this is due to cracks in seeds walls and the water entry through those cracks.

Soaked seeds with $\mathrm{NaOH}$, Showed relatively superiority in the seeds germination percentage than $\mathrm{HCl}$, and Scratched seeds, but those superiorities were not significant. Interaction between seeds sizes and removal testa treatments, defined that big seeds sizes treated with Hcl and small seeds size treated with $\mathrm{NaOH}$, obtained higher significant differences than others. Those results corresponded with the findings of Srivastava and his colleagues [14].

Table 3: Initial germination percentage for Ecuadelje variety with different seeds size and removal testa treatments

\begin{tabular}{|c|c|c|c|c|c|}
\hline \multirow[t]{2}{*}{ Seeds Size (A) } & \multicolumn{4}{|c|}{ Removal testa treatments (B) } & \multirow[t]{2}{*}{ Mean (A) } \\
\hline & bo & $\mathbf{b}_{1}$ & $\mathbf{b}_{2}$ & b3 & \\
\hline $\mathrm{a}_{1}$ & 16.6 & 37.5 & 72.0 & 32.0 & 39.53 \\
\hline $\mathrm{a}_{2}$ & 13.3 & 40.0 & 52.3 & 32.0 & 34.40 \\
\hline$a_{3}$ & 13.3 & 72.5 & 58.3 & 40.3 & 46.10 \\
\hline Mean $(\mathrm{B})$ & 14.4 & 50.0 & 60.9 & 40.0 & \\
\hline \multicolumn{3}{|c|}{$\begin{array}{l}\text { L.S.D } \\
\text { L.S.D. } \\
0.05\end{array}($ A X B $)=17.472$} & & & \\
\hline
\end{tabular}


$\mathrm{a}_{1}=$ Large seeds size $\mathrm{a} 2=$ Medium seeds size $\mathrm{a} 3=$ Small seeds size $\mathrm{b}_{0}=$ Seeds soaking with waterb $_{1}=$ Seeds soaking with diluted $\mathrm{HCl}$ b2 $=$ Seeds soaking with diluted $\mathrm{NaOH}$ b3 = seeds scarification

\subsection{Final Germination Percentage}

Table (4) demonstrates that there were not significant differences within seeds sizes on final germination percentage. While for treats of removal testa, seeds soaked with $\mathrm{NaOH}$ attained superior significant differences than those soaked with $\mathrm{HCl}$, and this treatment got significant superiority in germination percentage than seeds scratching. On the other hand treatment of scratching seeds was significantly outperformed than soaking seeds with water.

These results confirmed that it is possible to evolve the germination percentage of the stored seeds by soaking with $\mathrm{NaOH}$, HCI or at least scratching the seed shells. The same results obtained by the Agarwaland his colleagues $[15,16]$ but for the development of barley seeds by soaking with GA3 (concentrated100 ppm).Interaction between seeds sizes and removal testa treatments indicated that, large seeds soaked with $\mathrm{NaOH}$, small seeds soaked with $\mathrm{HCl}$, medium and small seeds soaked with $\mathrm{NaOH}$, were superior significant in germination percentage than soaked with diluted water. We concluded that soaking treats either in $\mathrm{NaOH}$ or $\mathrm{HCl}$ were better than scarification.

Table 4: Final germination percentage for Ecuadelje variety with different seed's sizes and different removal testa treatments

\begin{tabular}{|c|c|c|c|c|c|}
\hline \multirow[t]{2}{*}{ Seeds Size (A) } & \multicolumn{4}{|c|}{ Removal testa treatments (B) } & \multirow[t]{2}{*}{ Mean (A) } \\
\hline & bo & $\mathbf{b}_{1}$ & b2 & b3 & \\
\hline $\mathrm{a}_{1}$ & 23.6 & 52.8 & 80.3 & 44.4 & 50.28 \\
\hline$a_{2}$ & 16.2 & 54.1 & 72.7 & 45.9 & 47.23 \\
\hline $\mathrm{a}_{3}$ & 17.3 & 79.4 & 75.2 & 51.6 & 55.87 \\
\hline Mean (B) & 19.03 & 62.10 & 76.07 & 47.30 & \\
\hline \multicolumn{6}{|c|}{$\begin{array}{l}\text { L.S.D }{ }_{0.05}(A)=28.432 \\
\text { L.S.D }{ }_{0.05}(B)=15.547 \\
\text { L.S.D }{ }_{0.05}(\text { A X B })=12.873\end{array}$} \\
\hline
\end{tabular}

$\mathrm{a}_{1}=$ Large seeds size $\mathrm{a}_{2}=$ Medium seeds size $\mathrm{a}_{3}=$ Small seeds size $\mathrm{b}_{0}=$ Seeds soaking with water $\mathrm{b} 1=$ Seeds soaking with diluted $\mathrm{HClb}_{2}=$ Seeds soaking with diluted $\mathrm{NaOH} \quad \mathrm{b}_{3}=$ seeds scarification

\section{References}

[1] A. IUPOV,“ Broad bean (ViciafabaL.) (2003), Technical Questions: 206/1,“ International Union for Production Origen Varieties of plants, Hungary.

[2] C.Mohan Saxena and A. Richard Stewart, (1983), Faba bean in the Nile Valley: Aleppo, First Phase of the CARDA/IFAD Nile Valley Project, Syria.

[3] A. Franklin. Gondim, Enéas Gomes-Filch, Claudivan F. Lacerda, L José, Tarquinio Prisco, D. André Azevedo, C. Netoand,Marques, (2010), " Pretreatment with H2O2 in maize seeds, effects on germination and seedling acclimation to salt stress, Braz. J. Plant Physiol. vol.22 no.2 Londrina.

[4] A.Monica van Wensveen, (2008), Growing broad beans," Available online at www.cogs.asn.au. 
[5] F. A. Gharib and A. Z Hegazi.(2010), "Salicylic Acid Ameliorates in seeds Germination, Seedling Growth, Phyta hormone and Enzymes Activity in Bean (PhaseolusvulgaisL.) Under Cold Stress, Journal of American Science, volume 6 (10),pp. 675 - 683.

[6] J.E.C.MarcVander,Bart Van der Veen, C.M Joost., Hans Leemhuis\& L. Dijkhuizen, (2002), Properties and application of starch- converting enzymes of the- amylase family, "Journal of biotechnology, Volume (94), pp. 137-155.

[7] Gerhard Leubner, Metzger (2003), Functions and regulation of 1, 3-glucanase during seed germination, dormancy release and after-ripening, 'Seed Science Research, Volume (13), pp. 17 34.

[8] D.Enneking\& N. Maxted (1995), Narbon bean (Vicianarbonensis L.), Evolution of Crop Plants, N. Longman press, London.

[9] S Agarwal, RK Sairam, GC Srivastava , A Tyagi, RC Meena (2005), Role of ABA, salicylic acid , calcium and hydrogen peroxide on antioxidant enzymes induction in wheat seedlings, " Journal of Plant Science, Volume (169), pp. 559-570.

[10] S .Beebes, (2000), Research on common beans in Lateen America,' Journal of Grain Legumes, Volume (28), pp. 25 - 26.

[11] Zouhier Abbes, FadhalSellemii, Moes Amir \& Mohamed Kharii (2011), Variation in the resistance of some faba beans genotype to Orobanchecrenata," Pakistan Journal of Botany, volume (43), pp. 316- 325.

[12] AlraweeKashaa, M. \& Abdul Aziz Kalaf Allah(1985), Agriculture Experimental Design and Analysis, Mussel University press,Mussel.

[13] Hans Weber, Ute Heim, Sabine Golombek, LjudmillaBorisjuk and Ulrich Wobus(1998), Assimilate uptake and the regulation of seed development,' Seed Science Research, volume (8), pp.331-345.

[14] A.Srivastava, J.P. and L.T. Simarski, (1986), Seed Production Technology: (ICARDA), Aleppo, Syria.

[15] B.McDonald Miller (1994), Physiological of seeds germination, OhioState University press, Ohio.

[16] Jalal Omer Ahmed, Anwar Rashid Abdulla and Ribwar Ali Mohammed (2016), AmericanEurasian J. Agric. \& Environ. Sci, Volume 16(3), pp.635-640.

\footnotetext{
*Corresponding author.

E-mail address: jalal.ahmed@ spu.edu.iq
} 